\title{
DEVELOPMENT OF FLUVIO-LACUSTRINE SYSTEMS IN THE YOUNG GLACIAL AREA IN POLAND BASED ON THE RESEARCH IN THE VALLEYS OF THE RIVERS WIERZYCA AND WDA
}

\author{
MirosŁaW BŁASZKIEWICZ \\ Polish Academy of Sciences, Institute of Geography and Spatial Organization, \\ Department of Lowlands Geomorphology and Hydrology, Toruń, Poland
}

Manuscript received: December 20, 2009

Revised version: August 1, 2010

BŁAsZKIEWICZ M., 2010. Development of fluvio-lacustrine systems in the young glacial area in Poland based on the research in the valleys of the rivers Wierzyca and Wda. Questiones Geographicae 29(3), Poznań 2010, pp. 13-19. ISBN 978-83-62662-04-3. ISSN 0137-477X. DOI: 10.2478/v10117-010-0018-1.

\begin{abstract}
AвSTRACT. Both rivers presented in the article, the Wierzyca River and the Wda River, flow along typical polygenic valleys in young glacial areas. Their valleys include a number of postglacial basins, mainly subglacial channels connected by gap sections. The course of fluvial processes in postglacial basins was determined by the Late Glacial melting and the development of lakes. In Holocene, on the lacustrine and delta deposits, which were filling up the lake basins, wide meander zones with meandering river beds developed. In Late Glacial erosive processes dominated at the gap sections, which ended up with the development of slide meanders. Since the beginning of Holocene, lateral erosion has been dominant due to stabilization of the river bed. This has lead to the widening of the floodplain. Despite this, along the major course of both valleys the width of the floodplains is insufficient for free development of river channels. This is the case of constrained meandering.
\end{abstract}

KEYwords: young glacial area, Late Glacial, Holocene, post-glacial valley evolution

Mirostaw Błaszkiewicz, Polish Academy of Sciences, Institute of Geography and Spatial Organization, Department of Lowlands Geomorphology and Hydrology, Kopernika 19, 87-100 Toruń, Poland, e-mail: mirek@geopan.torun.pl

\section{Introduction}

Most research on fluvial geomorphology is conducted in river valleys located in extraglacial areas beyond the extent of the last glaciation. These valleys have had a long fluvial history, which allowed them to reach the mature stage of development. Recent changes of fluvial processes in these valleys are the result of natural climatic and vegetal fluctuations as well as the increasing anthropopression.

The development of river valleys in young glacial areas started already at the retreat of the Upper Vistulian ice sheet. There has not been enough time for a full development of valley landforms and, in most cases, the direction of fluvial processes was strongly influenced by morphogenesis of the earlier originated depressions 
subsequently incorporated by rivers into their systems.

The outstanding scientific interest in the young glacial area of Poland was concentrated on large streamways and valley forms, mainly on the Noteć-Warta Streamway and the seaside ones as well as the Lower Vistula River Valley and the Lower Oder River Valley. R. Galon (1961, 1967, 1968, 1972), summarizing his research on the morphogenesis of the Lower Vistula Valley (Galon 1934) and its tributary valleys (Galon 1953; Niewiarowski 1968) as well as the studies carried out in the Noteć-Warta Streamway (Kozarski \& Szupryczyński 1958; Kozarski 1962, 1965), suggested 'the streamway-gap' model for the development of valley and river systems which was closely related to the recession stages of the last ice sheet.

Due to the development of modern research techniques, mainly to a wider use of the absolute dating, the model described has been significantly modified (Drozdowski 1974, 1982; Drozdowski \& Berglund 1976; Wiśniewski 1976, 1982, 1985, 1990; Niewiarowski 1987; Andrzejewski 1994; Starkel 2001). Additionally, more and more reports on the existence of landforms related to the existence of dead ice blocks in the low valley floor morphological levels in the Lower Vistula River Valley (incl. Skompski 1969; Drozdowski 1974; Wiśniewski 1985, 1990; Kordowski 2004) induce a critical opinion over the model in question which stresses to much the role of fluvial erosion in origin of the valleys. As a result, a number of authors agreed that the main outline of the young glacial valley system had existed already prior the last glaciation (Brykczyński 1986; Koutaniemi \& Rachocki 1987; Rachocki 1992; Rachocki \& Koutaniemi 1993).

Geomorphological investigations within smaller valley forms began a bit later than in the large river ones. However, even the first studies revealed their morphological complexity (Murawski 1963, Basalykas 1968, Sylwestrzak 1973a, 1978a, b; Piasecki 1982). As the conducted researches show, they are predominantly polygenetic forms, which consist of sections with different genesis linked to the processes acting while the development and retreat of the last ice sheet, connected by gap river sections. On the one hand, the leading criterion in the typology of such river valleys is the genesis of the primary depressions (Basalykas 1968; Sylwestrzak 1978b), while, on the other hand, it is the level of fluvial transformation (Falkowski 1971). There have also been some attempts to combine valley classifications merging both typologies (Andrzejewski 1994).

This paper presents selected issues concerning the development of the Wierzyca River and Wda River valleys. The Wierzyca River valley is located directly behind the maximum extent of the Pomeranian Phase, predominantly within morainic plateaus, while the Wda River valley is located in front of this maximum stage within the East Pomeranian outwash plains. Despite differences in both the geomorphic settings and their relation to the maximum range of the Pommeranian phase in East Pomerania, morphogenetically the valleys are very similar. The rivers evolving in that area included into their systems a number of genetically different depressions, mainly various systems of subglacial channels. The valley sections between them, mainly the gap type, beside a narrow floodplain also include a few erosive terraces.

\section{The Wierzyca River valley}

The Wierzyca River valley is a typical example of a polygenetic river valley in the young glacial area. It is possible to divide it into three morphogenetic sections: the upper section, the lower one and the river-mouth section (Błaszkiewicz 1998).

The upper section is composed of subglacial channels, glacial depressions and irregular meltout hollows, which are connected to each other by short overspill channels. The level of fluvial transformation of these primary depressions, initial for the river flow, is insignificant. Generally, the fluvial relief at this section is represented only by small river bank undercuts as well as scours and crevasse in fluvial and limnic accumulation forms which are found within the depressions. The surfaces of depressions are built of lacustrine and peaty sediments with sandy deltaic deposits, which are the basis for the development of meander belts. Lakes in the individual depressions along the Wierzyca Valley developed asynchronically. In most of the depressions lakes come into being in Alleröd. In a few cases how- 
ever, an earlier, pre-Alleröd generation of lakes was documented. Moreover, there also exists some evidence that in some subglacial channels lakes originated as late as in pre-Boreal. The main reason for this asynchronity was a diversified process of dead ice blocks melting blocks which preserved the depressions. The other research, conducted by the author on the lake depressions in Tuchola Pinewood and in Kociewie Lakeland, indicates the dependence of the melting processes on a number of local factors. One of the main ones was the relation between the depressions and the developing system of the surface drainage (Błaszkiewicz 2005).

The lower section of the Wierzyca River valley is a young erosive landform which was strongly overshaped by fluvial processes; only in some sections does it use subglacial channels. The Late Glacial downcutting of the river channel into the morainic and fluvioglacial deposits led to the development of the lag, relatively resistant to being washed away. This forced the lateral movements of the river channel. As a result of simultaneous downcutting and lateral erosion, characteristic slide meanders developed which include erosive meadow terraces. Consequently, the valley became asymmetric. However, the river did not manage to develop a floodplain wide enough for the development of free meanders. Such a mature stage of the development has been reached only in the river-mouth section of the Wierzyca River valley.

\section{The Wda River valley}

The Wda River valley is an example of a fluvial form developed within the outwash plain (Okołowicz 1956; Sylwestrzak 1973a, 1978a). In the proximal part of the outwash plain there were distinguished eight outwash levels, which are linked with the retreat stages of the ice sheet from the maximum range of the Pomeranian Phase (Augustowski \& Sylwestrzak 1973; Sylwestrzak 1973a, b, 1978a; Szupryczyński 1987, 1988). The studies conducted at the mouth section of the outwash and of the Wda Valley indicate the existence of either three (Drozdowski 1967) or two outwash levels (Andrzejewski 1994), as well as about fifteen fluvial erosive terraces (Andrzejewski 1994).
The author conducted his geomorphological research along the middle section of the Wda River valley between the settlements of Wojtal and Stara Rzeka. The results indicate the outwash areas along the Wda River valley lack distinctive outwash levels which might have been related to the subsequent recession stages of the Pomeranian Phase ice sheet. Generally, it is a single outwash area of complicated morphology, which resulted mainly from the subsequently active melting and aeolian processes. At numerous places the outwash surface is a typical pitted outwash plain (incl. Wiśniewski \& Karczewski 1978). The main outwash area contacts with the outwash branches of the central part in the Vistula Lobe. Regarding morphogenesis only a high outwash level near Stara Kiszewa originated, due to analysis of its characteristic sedimentation, on ice contact edge (Błaszkiewicz 1998). It seems that the other local morphological levels of the outwash are only topographic surfaces in accordance to the definitions of Wiliams \& Rust (1969) as well as Miall (1983). They are related to periodic hydrodynamic changes of the meltwater accumulating the outwash plain.

Despite the fact that almost the entire middle section of the Wda River valley was incised into the outwash plain, regarding its morphogenesis it is very similar to the upper section of the Wierzyca River valley which is located within the Vistula Lobe. Along most of the course in this section the Wda River uses a diversified system of subglacial channels. They are connected by erosive river gap sections along which, besides relatively narrow floodplain, two or, locally, three fluvial-erosive meadow terraces are found. It implies that the erosive sections were mainly incised into the lowest topographic levels on the outwash plain, i.e. into the continuously active braided river channels (Miall 1983). Due to intensive fluvial erosion their primary morphology is almost invisible in the recent relief of the Wda River valley. Such a use of braided forms by a river crossing the outwash area was already described in the lower section of the Wierzyca River valley, to the east of Starogard Gdański (Błaszkiewicz 1998). Preliminary geomorphological observations, carried out by the author, indicate that the River Prusina, the tributary of the River Wda, along almost its entire course uses 
braided forms of the lowest topographic level in the Wda's outwash plain.

The channel sections used by the Wda River in its middle course have been significantly transformed by the fluvial processes. The level of fluvial transformation of the channel forms is much greater than it is in the case of both the upper section of the Wierzyca Valley (Błaszkiewicz 1998) and the upper section of the Wda River valley down to Lake Wdzydze (Kugler 2000). This is mainly caused by a more voluminous discharge through the primary depressions. This is not only visible in the changes of channels morphology but also in more frequent occurrence of alluvial deposits than lacustrine ones on the valley floor.

Fluvial and lacustrine landforms and deposits founded in this section of the valley indicate a river which joins lakes existing in valley basins and, simultaneously, a river which in Late Glacial systematically cuts through the gap sections between these depressions. Channel lakes which have been included into the Wda River valley mainly started to develop either during the Bölling-Alleröd Complex or in pre-Boreal (the Borzechów Channel at the contact with the Wda River valley). Similarly to the lakes in the Wierzyca River valley, the reasons for diverse timing of lake creation is possibly the complexity of melting out of the buried dead ice blocks which, in turn, depended on the local morphology and its relation to the surface draining. The prolonged survival of the dead ice blocks was only possible in those sections of the channels which in Late Glacial were not thermally influenced by water (Błaszkiewicz 2005). In accordance with the results of the research, intensive incision in erosive sections of the Wda River valley took place during the Bölling-Alleröd Complex. The existence of a numerous intermediate local erosion bases in the medium section of the Wda River valley in the form of lakes as well as a similar set of terraces between them indicate that the climatic and vegetal changes during the Bölling-Alleröd Complex were the main reasons for the river's incision. Erosive tendency favoured draining out of subglacial channels in many sections of the Wda River valley and preserving buried dead ice blocks in some areas until pre-Boreal. Systematic downcutting of the Wda River in the Late Glacial is mentioned by the authors dealing with the geomorphic development in its mouth section (Szupryczyński 1987, 1988; Andrzejewski 1994). Besides, in this part of the valley, often beneath the modern river channel, lacustrine deposits are recorded. In the vicinity of Przechowo near Świecie the bottom of these deposits has been dated as the Atlantic Period (Szupryczyński 1987).

Only in Younger Dryas erosive processes acting at the floor of the Wda River valley stabilized and the dominating incision gave way to lateral erosion. This was also the time of intensive deltas accumulation at places where the river flowed into the lakes which developed along its course. At the beginning of the pre-Boreal Period the Wda River generally reached the level of the modern meadow terrace in its gap sections.

At the beginning of the Holocene the last large changes in the Wda River valley took place, including the vicinity of Szlaga where a dry unused section of the asymmetric meander valley of about $3 \mathrm{~km}$ is recorded. Fluvial structures are clearly visible within this abandoned valley reach. They include an erosive-accumulative meadow terrace and an old floodplain with persisted on the surface channels filled up with biogenic deposits. Palynological analyses and radiocarbon data of these deposits, as well as of the lacustrine deposits below the fan delta at the mouth of the dry valley (a metre of carbonate gyttja below the 18-metre fan series of the sandy-gravel deposits) indicate that this form was active during the entire Late Glacial and was abandoned by the Wda River possibly at the turn of Younger Dryas and pre-Boreal. The recent river in this area flows within the subglacial channel. The change in the course of the River Wda was connected with the course of the melting processes in the channels, which is indicated by the deposits there: pre-Boreal basal peat covered with the lacustrine and fluvial deposits at the significant depths of up to $20 \mathrm{~m}$ below the modern floodplain.

\section{Development tendencies of the river valleys in young glacial areas}

The Late Glacial and Early Holocene evolution of the Wierzyca and Wda River valleys indicates that the process of the valley development in areas of the last glaciation was dynamic. Its course 
was tightly connected with morphogenesis of the primary depressions included into the valley systems and, predominantly, with the melting of the buried dead ice blocks and the development of lakes. In terms of their evolution lake depressions and river valleys in the young glacial areas make up interconnected hydrological systems (Koutaniemi \& Rachocki 1981; Drwal 1982; Niewiarowski 1988; Florek 1989, 1991; Andrzejewski 1994; Kalicki \& San`ko, 1997; Błaszkiewicz 1998; Helbig, De Klerk 2002, Kaiser 2001; Bajkiewicz-Grabowska 2002; Jaworski 2003; Rother 2003; Lorenz \& Schult 2004). Lakes which developed in Late Glacial and Early Holocene along the course of the rivers determined fluvial processes. They obviously influenced the hydrological regime of the rivers, mainly by decreasing the irregularity of the discharge (Bajkiewicz-Grabowska 2002). Lakes became local erosion bases in river valleys. They also trapped sediments transported by the river and in this way intensified erosion in the valley gaps. Delta fans entering lakes became the basis for the further development of fluvial processes. In this way in the inherited sections wide meander belts developed, within which rivers had been freely meandering until they were regulated. On the one hand, in such situations we deal with a young river which uses a depression of non-fluvial origin (Falkowski 1971, 1984 - type $\mathrm{Ib}$ ) and, on the other hand, with a mature river which freely shapes its bed only in accordance with the hydrodynamic conditions (Falkowski 1971, 1984 - type II). A very interesting example of the Late Glacial delta fan which enters bottom deposits of a developing lake was recorded at the contact of the Wda River with the Wiecz Channel (Błaszkiewicz 2005). A modern example of a Gilbert delta was recognized in the valley of the Płociczna River, the tributary of Drawa River, in Western Pomerania (Chudzikiewicz et al. 1979).

Analysis of the interrelations between the lacustrine and fluvial deposits makes it possible to date both Late Glacial and Early Holocene development tendencies in the erosive sections of the river valleys. At that time accumulation dominated in the inherited sections (deltas' growth, the input of the material from the abrasive-accumulative platforms on the shore and primary production in the lakes) and erosion was limited to small bank undercuttings and cutting through gaps. At the valley gap sections, however, erosive processes, mainly incision, dominated. In practice, only Younger Dryas was the period of time when the tendency to deepen the river channels slowed down in favour of lateral erosion. At this time the lowest meadow terrace developed in the studied valleys, and in the vicinity of Szlaga the Wda River was flowing at the level of the floodplain in the dry valley hanging section. The turn of the Younger Dryas and Early Holocene was the last period of time when large changes in evolution of the valleys took place. Simultaneously, after a short episode of incision, erosiveaccumulative processes in their floors stabilised significantly giving way to lateral migration of the river beds widening the floodplain.

During the Later Glacial phase of the river downcutting, in the valleys in question single river channels of low but growing sinuosity existed (development of slide meanders) in the Wierzyca Valley and, to some point, in the Wda River valley). Constant widening of the floodplain due to lateral erosion, which took place in Holocene, led to the development of a large number of erosive sections of the so-called constrained meandering (Popow 1968). The main factor which would limit lateral development of the river along this section was narrowness of the floodplain in relation to the river discharge.

Models accepted for the period of time in question assume that the river channels, affected by climatic conditions, turned from the braided pattern to the meandering one with a short phase of large meanders at the beginning of the Late Glacial (incl. Falkowski 1975; Kozarski \& Rotnicki 1978; Szumański 1983; Florek 1991; Rotnicki 1991; Starkel 1988, 1991, 2001; Vandenberghe 1993, 1995; Mol et al. 2000; Gębica 2004). This model was predominantly based on the investigations carried out in the river valleys located outside the maximum range of the Vistulian Glaciation. Its modifications take into growing consideration the influence of the local relief and lithology on the evolution of the river channels and the timing of the threshold situations in the river valleys (Vandenberghe 2003).

Irrespectively of time differences in which individual valleys reacted to climatic changes, the application of the above model for young glacial areas is limited. Exceptions include the valley of 
the Spree River in the vicinity of Unterspreewald, i.e. the area which is located directly behind the maximum range of the Brandenburg-Leszno Phase, where all the above generations of river channel patterns were recorded (Błaszkiewicz \& Juschus 1999). However, the quoted example in the described section of the Spree River valley developed within the flat outwash plain built of monolithic fine-grained sands, where the depth of the consecutive scours was maximum $2 \mathrm{~m}$ and the significant width of the valley floor favoured the survival of the individual development phases. To study the development of the river valley in areas within the range of the last glaciation it is also necessary to consider the deglaciation process as well as geomorphic conditions in the analysed area, including melting out of the buried dead ice blocks and the lakes development (Koutaniemi \& Rachocki 1981; Florek 1991; Andrzejewski 1994; Błaszkiewicz 1998; Starkel 2001; Rother 2003).

\section{Acknowledgements}

The investigation is founded by the Polish Ministry of Science and Higher Education (grant No. N306 0318 33). Text translated by Aleksandra Zaparucha.

\section{References}

ANDRZEJEWSKi L., 1994. Ewolucja systemu fluwialnego doliny dolnej Wisły w późnym vistulianie i holocenie na podstawie wybranych dolin jej dopływów. Rozprawy Uniwersytetu Mikołaja Kopernika, Torun.

Augustowski B. \& Sylwestrzak J., 1973. Z morfogenezy centralnej części Pojezierza Kaszubskiego. Przegląd Geograficzny 45(1): 51-64.

BAJKIEWICZ-GRABOWSKA E., 2002. Obieg materii w systemach rzeczno - jeziornych. Uniwersytet Warszawski, Wydział Geografii i Studiów Regionalnych, Warszawa.

BASALYKAS A., 1968. Różnorodność morfogenetyczna dolin krajobrazu polodowcowego na przykładzie terenów Litewskiej SSR. Przeglad Geograficzny 40(4).

BŁaszKIeWICZ M., 1998. Dolina Wierzycy, jej geneza oraz rozwój w późnym plejstocenie i wczesnym holocenie. Dokumentacja Geograficzna 10.

BŁaszKiewicz M., 2005. Późnoglacjalna i wczesnoholoceńska ewolucja obniżeń jeziornych na Pojezierzu Kociewskim (wschodnia część Pomorza), Prace Geograficzne 201.

BŁAsZKIEwicz M. \& Juschus O., 1999. Late-glacial and EarlyHolocene Development of the Spree River Valley at the Back of the Brandenburg Phase (Unterspreewald - Germany). Quaternary Studies in Poland, Special Issue: 249252.
BRYKCZYŃSKI M., 1986. O głównych kierunkach rozwoju sieci rzecznej Niżu Polskiego w czwartorzędzie. Przegląd Geograficzny 53(3): 411-440.

Chudzikiewicz L., Doktor M., Gradziński R., Haczewski G., Leszczyński S., Łaptaś A., PawetczyK J., PorębSKi S., RaCHOCKi A. \& TuRnau E., 1979. Sedymentacja współczesnej delty piaszczystej w jeziorze Płociczno (Pomorze Zachodnie). Studia Geologica Polonica 62.

DrozDowsKi E., 1967. Objaśnienia do mapy geomorfologicznej 1: 50 000, ark. Chełmno, Dokumentacja Geograficzna 2.

Drozdowski E., 1974. Geneza Basenu Grudziądzkiego w świetle osadów i form glacjalnych, Prace Geograficzne IGiPZ PAN 104.

DrozDowski E., 1982. The evolution of the Vistula river valley between the Chełmno Basin and the Grudziądz Basin. Geographical Studies, Special Issues 1: 131-148.

DrozdowsKi E. \& Berglund B.E., 1976. Development and chronology of lower Vistula valley, North Poland. Boreas 5: 95-107.

DRWAL J., 1982. Wykształcenie i organizacja sieci hydrograficznej jako podstawa oceny struktury odpływu na terenach młodoglacjalnych, Zesz. Nauk. UG, Rozprawy i Monografie 33.

FALKOWSKI E., 1971. Historia i prognoza rozwoju koryta wybranych odcinków rzek nizinnych Polski. Biuletyn Geologiczny 12: 5-121.

FALKOWSKI E., 1975. Variability of channel processes of lowland rivers in Poland and changes of the valley floors during the Holocene. Biuletyn Geologiczny 19: 45-78.

FALKOWSKI E., 1984. Sposoby poziomego rozwinięcia koryta rzecznego w morfogenetycznie zróżnicowanych odcinkach dolin rzecznych. Przeglad Geofizyczny 29(4): 497501.

FLOREK W., 1989. Postglacjalna ewolucja doliny Słupi. Studia i Materiaty Oceanologiczne 56, Geologia Morza 4: 237-249.

FLOREK W., 1991. Postglacjalny rozwój dolin rzek środkowej części pótnocnego skłonu Pomorza. WSP, Słupsk.

GALON R., 1934. Dolina dolnej Wisły, jej kształt i rozwój na tle budowy dolnego Powiśla, Badania Geograficzne nad Polska pótnocno-zachodnia 12-13.

GaLON R., 1953. Morfologia doliny i sandru Brdy. Studia Societatis Scientiarum Torunensis, ser. C 1(6).

Galon R., 1961. Morphology of the Noteć-Warta (or TorunEberswalde) ice marginal streamway, Geographical Studies 29.

Galon R., 1967. Czwartorzęd Polski Północnej. In: Czwartorzęd Polski, PWN, Warszawa: 106-166.

GALON R., 1968. New facts and problems pertaining to the origin of the Noteć-Warta Pradolina and the valleys linked with it. Przeglad Geograficzny 40(2): 307-315.

GALON R., 1972. Geomorfologia Polski, Tom II. PWN, Warszawa.

GĘBicA P., 2004. Przebieg akumulacji rzecznej w górnym vistulianie w Kotlinie Sandomierskiej. Prace Geograficzne 193.

Helbig H. \& De Klerk P., 2002. Befunde zur spätglazialen fluvial-limnischen Morphodynamik in kleinen Talungen Vorpommerns. Eiszeitalter und Gegenwart 51: 51-66.

JAwORSKI T., 2003. Morfogeneza rynny i doliny Welu. MS, Uniwersytet Mikołaja Kopernika, Torun.

KAISER K., 2001. Die spätpleistozäne bis frühholozäne Bekkenentwicklung in Mecklenburg - Vorpommern. Greifswalder Geographische Arbeiten 24.

KALICKI T. \& SAN`KO A., 1997. Ewolucja doliny Łuczosy w późnym glacjale i holocenie, Dokumentacja Geograficzna 6: 53-82. 
KORDOWSKI J., 2004. Osady i rzeźba doliny Wisły w okolicach Chełmna i Świecia. In: W. Chudziak (ed.), Wczesnośredniowieczny zespół osadniczy w Kałdusie. Studia przyrodniczo-archeologiczne, Wydawnictwo UMK: 43-68.

KoutAniemi L. \& RAchocki A., 1981. Palaeohydrology and landscape development in the middle course of the Radunia basin, North Poland. Fennia 159(2): 335-342.

KOUTANIEMI L. \& RACHOCKI A.H., 1987: Origin of pradolinas. Zeitschrift für Gletscherkunde und Glazialgeologie 23: 65-76.

KOZARSKI S., 1962. Recesja ostatniego lądolodu z północnej części Wysoczyzny Gnieźnieńskiej a kształtowanie się Pradoliny Noteci-Warty. Prace Komisji Geograficzno-Geologicznej PTPN 2(3).

KoZARSKI S., 1965. Zagadnienie drogi odpływu wód pradolinnych z zachodniej części pradoliny Noteci-Warty. Prace Komisji Geograficzno-Geologicznej PTPN 5(1).

KOZARSKI S. \& ROTNICKI K., 1978. Problemy późnowürmskiego i holoceńskiego rozwoju den dolinnych na Niżu Polskim. Prace Komisji Geograficzno-Geologicznej PTPN 19.

KOZARSKI S. \& SZUPRYCZYŃSKI J., 1958. Terasy pradoliny Noteci między Nakłem a Milczem. Przegląd Geograficzny 30(4): 671-681.

Kugler T., 2000. Kilka uwag o stanie badań rzeźby doliny Wdy. Rocznik Fizycznogeograficzny UG, V: 107-114.

LoRenz S. \& Schult M., 2004. Das Durchbruchstal der Mildenitz bei Dobbertin (Mecklenburg) - Untersuchungen zur spätglazialen und holozänen Talentwicklung an Terrassen und Schwemmfächern. Meyniana, 56: 47-68.

Miall A.D., 1983, Glaciofluvial transport and deposition. In: Glacial geology, An introduction for engineers and earth scientists: $168-183$.

Mol J., Vandenberghe J. \& Kasse C., 2000. River response to variations of periglacial climate in mid-latitude Europe. Geomorphology 33: 131-148.

Murawski T., 1963. Zagadnienie zmian biegu górnej Brdy. Zeszyty Naukowe UMK, Geografia 2: 25-44.

NieWiarowski W., 1968. Morfologia i rozwój pradoliny i doliny Drwęcy. Studia Societatis Scientiarum Torunensis 6(6), sec. C.

NieWIAROWSKI W., 1987. Evolution of the lower Vistula valley in the Unisław Basin and the river gap to the north of Bydgoszcz-Fordon. In: L. Starkel (ed.), Evolution of the Vistula river valley during the last 15000 years. Geographical Studies IGiPZ PAN, Special Issue 4: 233-252.

NieWIAROWSKI W., 1988. Levels in subglacial channels and their significance in determining the channel origin and evolution. Geographia Polonica 55: 113-127.

Окоєошісz W., 1956. Morfogeneza wschodniej części Pojezierza Pomorskiego. Biuletyn Instytutu Geologicznego 100, Z Badań Czwartorzędu w Polsce 7: 355-394.

Piasecki D., 1982. Ewolucja dolin rzek Przymorza. Przeglad Geograficzny 54(1-2): 49-68.

Popow J.W., 1968. Tipy riecznych pojm i ich swjazy z opriedielajuszczimi faktorami. In: Morfologiczeskije i gidrowliczeskije isledowanija riek i wodojemow, Trudy wyp. 155.

RAсHOCKI A.H., 1992. Przetrwałość pradolin Pobrzeża Kaszubskiego. Zeszyty Naukowe UG, Geografia 18: 97-118.

RACHOCKI A.H. \& KoutANIEMI L., 1993. The origin of pradolinas: A reassessment. Zeitschrift für Gletscherkunde und Glazialgeologie 27-28: 37-50.

RotNICKI K., 1991. Retrodiction of paleodischarges of meandring and sinous alluvial rivers and its paleoclimatic implications. In: K.J. Gregory (ed), Temperate Paleohydrology, Wiley, Chichester: 431-470.
Rother H., 2003. Die jungquartäre Landschaftsgenese des Nebeltales im Bereich der Pommerschen Hauptendmoräne bei Kuchelmiss (Mecklenburg). Greifswalder Geographische Arbeiten 29: 105-141.

SкомРКкі S., 1969. Stratygrafia osadów czwartorzędowych wschodniej części Kotliny Płockiej. Biuletyn Państwowego Instytutu Geologicznego 220: 175-258.

Starkel L., 1988. Historia dolin rzecznych w holocenie. In: Przemiany środowiska geograficznego Polski, Wszechnica PAN, Ossolineum: 87-107.

STARKEL L., 1991. Long-distance correlation of fluvial events in the temperate zone. In: K.J. Gregory (ed.), Temperate Paleohydrology Wiley, Chichester: 473-491.

Starkel L., 2001. Historia doliny Wisły od ostatniego zlodowacenia do dziś. Monografie IGiPZ PAN 2, Warszawa.

SylweStrZAK J., 1973a. Rozwój sieci dolinnej na tle recesji lądolodu w północno-wschodniej części Pomorza. Prace habilitacyjne UG 14.

SylwestrZak J., 1973b. Z zagadnień czwartorzędu Kościerzyny. Rocznik Polskiego Towarzystwa Geologicznego 43(4): 535-543.

SYlwestrzaK J., 1978a. Rozwój sieci dolinnej na Pomorzu pod koniec plejstocenu. Gdańskie Towarzystwo Naukowe.

SYlweStrZAK J., 1978b. Zagadnienie morfologii i typizacji dolin północnego skłonu Pomorza. Biuletyn Instytutu Geologicznego 306(21): 199-226.

SZUMAŃSKI A., 1983. Paleochannels of large meanders in the river valleys of the Polish Lowland. Quaternary Studies in Poland 4: 207-216.

SZUPRYCZYŃSKI J., 1987. Reliefentwicklung des Wda-Sanders. Math.-nat. wiss. Reihe, Greifswald 36(2-3): 15-19.

SZUPRYCZYŃSKI J., 1988. Morphology and ice melting in a pomeranian outwash plain, Wda valley. Geographia Polonica 55: $173-179$.

VAndenberghe J., 1993. Changing fluvial processes under changing periglacial conditions, Zeitschrift für Geomprphologie 88: 17-28.

VANDENBERGHE J., 1995. The role of rivers in palaeoclimatic reconstruction. In: B. Frenzel, J. Vandenberghe, C. Kasse, S. Bohncke, B. Gläser (eds.), Europen River Activity and Climatic Change during the Lateglacial and early Holocene, Paläoklimaforschung 14: 11-19.

VAndenberghe J., 2003. Climate forcing of fluvial system development: an evolution of ideas. Quaternary Science Reviews 22: 2053-2060.

Williams P.F. \& Rust B.R., 1969. The sedimentology of a braided river. Journal of Sedimentary Petrology 39: 649-679.

WiśnIEWSKI E., 1976. Rozwój geomorfologiczny doliny Wisły pomiędzy Kotliną Płocką a Kotliną Toruńską. Prace Geograficzne IGiPZ PAN 119.

WIŚNIEWSKI E., 1982. The geomorphological evolution of the Vistula river valley between Włocławek and Ciechocinek during the last 15000 years. In: L. Starkel (ed.), Evolution of the Vistula river valley, part I, Geographical Studies, Issue 1: 93-108.

WiśnIEWSKI E., 1985. Wiek terasy zalewowej Wisły pomiędzy Wyszogrodem a Płockiem w świetle datowań metodą radiowęglową. Przegląd Geograficzny 57(4): 553-559.

WiśNIEWSKI E., 1990. The lower Vistula Valley. In: Evolution of the Vistula river valley during the last 15000 years, Geographical Studies Special Issue 5: 146-153.

WiśNIEWSKI E. \& KARCZEWSKI A., 1978. O rzeźbie sandrów utworzonych na lodzie. Przegląd Geograficzny 50(2): 269-292. 